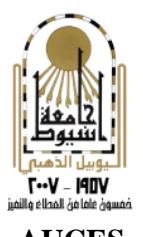

AUCES

\title{
NILE WATER HYACINTH PROCESSING \\ PART (I) CHEMICAL CHARACTERISTICS OF HUMIC ACIDS EXTRACTED FROM NATURALLY HUMIFIED NILE WATER HYACINTH AND THEIR NATURAL HUMATES EFFECT ON MAIZE GRAIN YIELD
}

\author{
M. H. Bader * and Fatema Abed Al-Hamide Nofel ${ }^{* *}$ \\ *Chemistry Department, Faculty of Science Al-Azhar University for Girls, and **Corn Department, \\ Field Crops Institute ,ARC, Cairo, Egypt
}

\begin{abstract}
:
Nile Water hyacinth heaps collected from Nile water surface are environment good for humifications processes. In this research, humic acids (HAs) were extracted from Nile Water hyacinth clay by $0.1 \mathrm{M} \mathrm{NaOH}$ after $2 \mathrm{~h}$ extraction. The elemental analyses of these purified, and air- dried humic acids are calculated on dry and ash free base are in general agreement with those found in literatures for humic acids. The atomic ratios of $\mathrm{H} / \mathrm{C}, \mathrm{O} / \mathrm{C}$, and N/C characterizing the obtained humic acids are 1.123, 0.399, and 0.105 respectively. The content of $\mathrm{COOH}$ groups and $\mathrm{OH}$ groups give a total acidity of $7.39 \mathrm{meq} / \mathrm{g}$ which it means that the acids are biologically active and of moderate acidity. The prepared, naturally soluble humates solution becomes turbid and its absorbance decreases with time where its absorption spectra still remains of the same character with time. The decreasing rate constant, $(\mathrm{k})$ and the half life time, $\left(\mathrm{t}_{0.5}\right)$ are $6.281 \times 10^{-3}$ day ${ }^{-1}$ and 4.59 day respectively. Accordingly, the soluble humates solution undergoes a decrease in the concentration with time and it is preferable to be prepared freshly before use as possible to avoid these chemical changes which may reduce its activity. With treating the maize plant by soaking seeds with the natural humates stimulating solution of $0.012 \%$ OC (about 0.24 gm HAs/L) for 24 hours before planting in a sandy soil, the grain yield increase to $31.13 \mathrm{ard} / \mathrm{fed}$ compared to $26.88 \mathrm{ard} / \mathrm{fed}$ for the control, in the first year and to $34.12 \mathrm{ard} / \mathrm{fed}$ compared to $30.91 \mathrm{ard} / \mathrm{fed}$ for the control in the second year. This suggests the importance of using humic acids for improving the stress tolerance of maize plants in the sandy soil.
\end{abstract}

\section{INTRODUCTION:}

\section{Water hyacinth definition:}

The unknown Gift of Nature: The water hyacinth (Eichhornia crassipies) is considered the worst weed plant which grows on water. It grows well in the shallow water where it is able to extract nutrients from soil but it does very poorly in the deep water. In general, the plant was found to consist of $\mathbf{1 7 . 6 8 \%}$ leaves, $\mathbf{4 3 . 7 8 \%}$ petioles and $38.54 \%$ roots on a green base with 
average moisture contents of $90.87,95.49$ and $86.54 \%$ respectively. It is capable of multiplying faster than any other known fresh water plant. It can double its size every ten days. During its usual 8 month growing season (in some tropical climate) ten plants can cover 0.45 hectares. It produced as many as 90 million seeds per hectare which remain viable and able to germinate up to 20 years (zerrudo et al. 1983). Water hyacinth grows profusely and forms a compact mat on the water surface. The mat traps dust as well as organic matter (Sharma and Goel, 1987). It has high capacity to absorb pollutants and toxicants beside its property to accumulate heavy metals, such as $\mathrm{As}, \mathrm{Cd}, \mathrm{Cu}$, $\mathrm{Pb}$ and $\mathrm{Zn}$ in the roots and tissues. It has been used for the removal and the recovery of silver from the industrial waste and for the waste water treatment. Water hyacinth can produce insect growth inhibitory compound and it can be used in silage production (sidique and Alam, 1990). Studies on utilization of water hyacinth have been indicated that the fibers recovered from the petioles may be used for pulping and paper making. (Zerrudo et al., 1983).

Humic matter has significant an impact on the development of plant organisms. The optimum plant growth can be obtained by a combined effect of humic substances and mineral nutrients (Garcia et al., 1994; Arancon et al., 2004). Humic substances stimulate the growth and division of the plant cells. They enhance plant circulatory systems, and promote optimum plant respiration and decrease the plant stress and premature deterioration. They dramatically improve the seed germination and promote greater the fibrous root growth. They also increase the size of legume root and the number of nodules and increase the resistance to drought, and insect infestation. In addition, they modify and improve the structure of the soil, and reduce the over salinity, and fight against soil erosion (Ayuso et al., 1996, Tan 1998, Eladia et al., 2005).

On other hand, water hyacinth has become a worldwide problem due to its spreading and water pollution character. People have been trying to remove the plant from water ways spending billions of dollars in doing this action. In Egypt, particularly in Al-Kanater El-Khyria area, the growth of water hyacinth plants is prevented. So the plants are collected from water ways and fired. This work aimes to utalize the Nile water hyacinth plants in production of humates solutions in order to be used in improving the crop production of maize plants. This work also includes the characterization of humic acids extracted from Nile water hyacinth by $0.1 \mathrm{M} \mathrm{NaOH}$ after twohour soaking in the absence of air and their use in the preparation of humates solution that is suitable for plant application.

\section{MATERIALS AND METHODS:}

\section{Nile water hyacinth processing:}

Nile water hyacinth plants that were mechanically collected from the water surface of the Nile were found to be accumulated in large heaps at the Nile bank and other water ways. The temperature of the heaps was raised spontaneously with the evolution of very large amounts of water vapor (which can be restored under controlled conditions). The heaps were stirred and then spread for drying in the air with the direct sun light. Most of the plant parts including fibers were decomposed and changed into a material like clay spices around plant stems was remained. These masses of Nile Water Hyacinth Clay (NWHC) were collected and ground into a clay powder. The clay powder was analyzed and used for a humic acid extraction. 


\section{Nile Water Hyacinth Clay (NWHC) Analysis:}

For the purpose of this research, the following analyses were carried out on the hyacinth clay: Organic carbon (OC) and total nitrogen (TN) were determined titeremetically according to (Standard methods of APHA et al. 1995). The pH of NWHC was measured according to (Wild, 1979) using pH-miter with glass combined electrode of type WTW PH 530. Both HA and FA content were estimated as organic carbon in the extracts as shown below.

\section{Humic acids extraction:}

The not decayed parts of the water hyacinth were removed as possible. Fifty grams of the water hyacinth clay powder were introduced into plastic bottles and $600 \mathrm{ml}$ of $0.1 \mathrm{~N} \mathrm{NaOH}$ were added. The air in the bottle was completely removed by the extracting solution. The bottle was shaken by inversing it several times during 2h interval. The dark bright brown extract was filtered out the solid residue by suitable tissue then its $\mathrm{pH}$ was lowered as quickly as possible to blow 2 using a dilute $\mathrm{H}_{2} \mathrm{SO}_{4}$. This leaded to precipitation of humic acid but the yellow fulvic acid remained soluble in the mother liquid. Humic acid left for coagulation, and then separated by filtration or centrifugation. OC and $\mathrm{TN}$ contents were determined for the two acids. The extracted humic acids were purified as described by, Badr (2003). The extraction and purification steps were repeated at $6 \mathrm{~h}, 16 \mathrm{~h}$, and $24 \mathrm{~h}$ extraction time intervals.

\section{Chemical and spectroscopic character- istics of the investigated humic acids:}

The following analyses were carried out on the samples of the purified humic acids extracted after $2 \mathrm{~h}$ soaking of the NWHC in 0.1M NaOH. Carbon, Nitrogen, and Hydrogen percentage were determined by using 2400, C N H Elemental Analyzer-Perkin Elemer. The absorptivity (a) was determined by measuring the absorbance at. $465 \mathrm{~nm}$ for a sodium humate solution. $Q_{4 / 6}$ was determined as ratio of the absorbances of sodium humates solution at $\mathbf{4 0 0}$ $\mathrm{nm}$ to that at $600 \mathrm{~nm}$ on Unicam uv/v 300 (England). The contents of $\mathrm{COOH}$ and $\mathrm{OH}$ groups were determined using $\mathrm{Ca}(\mathrm{OAc})_{2}$ and $\mathrm{Ba}(\mathrm{OH})_{2}$ according to the method which is modified by (Schnitzer and Umesh, 1965).

\section{Preparation of natural humates stimulating solution (Natural humates SS):}

Since $\mathrm{Cl}_{2}$ has a destructive effect on humic substance, (Yamada, et al. 1998), the water used for preparation of Natural hamates SS solution was underground water without any $\mathrm{Cl}_{2}$ treatment. Also, to avoid the high salinity, 0.1 M $\mathrm{KOH}$ is used in the final preparation of the humates SS solution and then neutralization was performed by a dilute $\mathrm{H}_{2} \mathrm{SO}_{4}$.

The natural humates stimulating solution was prepared as follows: A humic acids sludge obtained after 2 hours extraction by $0.1 \mathrm{M}$ $\mathrm{NaOH}$ was dissolved without any purification processes in a minimum amount of $0.1 \mathrm{M} \mathrm{KOH}$. The $\mathrm{pH}$ was lowered to 6-7 by a dilute $\mathrm{H}_{2} \mathrm{SO}_{4}$. This solution was diluted have $0.012 \%$ of $\mathrm{OC}$ (about $0.25 \mathrm{gm} \mathrm{HAs} / \mathrm{L}$ ). This solution was applied to study its effect on the grain yield of maize hybrid.

\section{Stability of humates solution:}

The natural humates SS solution was kept at room temperature and its stability was followed by measuring its absorbance at 254 , 436, 465 and $665 \mathrm{~nm}$ and the complete uv- vis spectra of the solution was recorded every $24 \mathrm{hr}$ for 4 days on the Unicam UV/V300 spectropho- 
tometer. The alternation rate constant $(k)$ and the half life time, $\left(\mathrm{t}_{0.5}\right)$ were calculated using the equation given by Olson (1963).

\section{Some analytical aspects of natural humate SS:}

The Natural humates SS was analyzed to obtain some parameters. TN, (total Nitrogen), TDS (total dissolved solids), BOD, (biochemical oxygen demand), COD (chemical oxygen demand) according to the (Standard methods of APHA et al. 1995) Naural humates SS. was digested using milles 4 tone microwave digestion lab station (Italy). Some important such as Mn, $\mathrm{Cu}, \mathrm{Fe}, \mathrm{Mo}, \mathrm{Zn} . .$. etc metals were determined in the digest by using the plasma optical emission mass spectrometer (POEM III) thermojarrell ash, USA.

\section{The application of natural humate SS for maize plant:}

Two field experiments were carried out in a sandy soil with the collaboration of Ismailia research station/Agricultural Research Center
(ARC), 9 Gamma Street, Giza, 12819, Cairo, Egypt. under sprinkler irrigation in 2005 and 2006 season to study the effect of the natural. humate SS on the grain yield of maize plants. The treatment including soaking seeds in (0. 25 g/l) of this solution for $24 \mathrm{~h}$ before planting. Suitable blanks were set up. The experimental design was randomized complete blocks with four repelcations.

\section{RESULTS AND DISCUSSION:}

Table (1) shows organic (OC) carbon, humic acids content and HA/FA ratio of the Nile water hyacinth clay (NWHC) in comparison with some other organic wastes. From comparison of data given, it obvious that the NWHC has a relatively low $\mathrm{OC}$ content, compared to the most of the indicated organic wastes, It is considered very rich source for humic acids in comparison with these wastes. This means that the collected Nile water hyacinth heap is a good environment for the humification process.

Table (1): Organic carbon (OC), hummic acids content (HAS) and HA/FA ratio of Nile-water hyacinth clay (NWHC) at pH 6.97, and moisture content of $7.85 \%$

\begin{tabular}{||c|l|c|c|c||}
\hline \hline No & \multicolumn{1}{|c|}{ Source } & OC \% & HAS mg/kg & HA/FA \\
\hline 1 & NWHC & 08.90 & 6000 & 1.25 \\
2 & Sewage sludge & 06.80 & 109.25 & 0.28 \\
3 & Village's compost fuel (VCF) & 37.0 & $24.6 \times 10^{3}$ & - \\
4 & Raw tea waste & 44.9 & 173.63 & - \\
5 & Composted spend mushroom & 20.00 & 092.00 & - \\
6 & Inorganic soil & 01.68 & 066.00 & - \\
\hline
\end{tabular}

No. 3 according to Badr, (2003) Nos, 2, 4, 5, and 6 according to Unsal and Sony (2006).

\section{NWHC as a rich source for Natural humate SS:}

The yield of humic acids extracted after 2,6 , 16 and $24 \mathrm{~h}$. was 1.6, 2.3, 6.8, and $8 \mathrm{gm} / 500 \mathrm{gm}$ of NWHC, respectively. It has been demonstrated that plant growth can be stimulated by a very low concentration of humic acid (Ayuso et al., 1996). Accordingly, the economic value of NWHC with respect to humates production can be observed from Table (2). After two hours, about 12 liter of the humates stimulating solution can be obtained. With increasing the time of extraction to $24 \mathrm{~h}$. 
the volume of himates solution may be increase to 64 liters. These large amounts of humates solutions can be used in testing the germination and growth of different plants and determining the condition suitable for increasing the production of each crop. The chemical and spectroscopic characteristics of humic acids extracted from the NWHC by $0.1 \mathrm{M} \mathrm{NaOH}$ after $2 \mathrm{~h}$ soaking, their natural humates, and their application on maize grain yield will be discussed later.

Chemical and spectroscopic characteristics of humic acids extracted from humified Nile water hyacinth after $2 \mathrm{~h}$ soaking by $0.1 \mathrm{M} \mathrm{NaOH}$ :

The elemental analysis of the purified, airdried humic acids is shown in the Table (3). These values are calculated on the dry and ash free basis and are in agreements with those found in literatures for HAs. (Stevenson, 1994, Rice, and MacCarthy, 1991). The atomic ratios of $\mathrm{H} / \mathrm{C}, \mathrm{O} / \mathrm{C}$, and $\mathrm{N} / \mathrm{C}$ that characterize these humic acids from are found to be $1.123,0.399$, and 0.105 respectively. These are close to those characterize humic acids extracted from peat (Alken et al., 1985).

The humification degree $\left(Q_{4 / 6}\right)$ is the ratio of the absorbance of humate solution at $400 \mathrm{~nm}$ to its absorbance at $600 \mathrm{~nm}$. It is related to its average molecular weight. According to the available data, the average molecular weight of 15000 to 30000 is corresponding to the $Q_{4 / 6}$ of about 5, (Tan, 1998). As the $Q_{4 / 6}$ of the investigated humic acids is equal to 4.75 their average molecular weight is expected to be within this range. Another spectroscopic property is the absorbance per unit of dissolved organic carbon, a, which it is an analog of the absorptivity. The value obtained is in Table (3) is in general agreement with the values obtained for humic acids extracted from soils. The contents of $\mathrm{COOH}$ group and $\mathrm{OH}$ groups give a total acidity of $7.4 \mathrm{meq} / \mathrm{g}$ which means that the acids are of a moderate acidity (Ludmila et al., 2005).

Table (2): Volumes of the natural humate SS (0.25 g/L) can be obtained from the Nile water hyacinth clay by $0.1 \mathrm{~N} \mathrm{NaOH}$ at different time intervals

\begin{tabular}{|c|c|c|c|c||}
\hline Extraction time in hours & 2 & 6 & 16 & 24 \\
\hline Volume (liter/kg) & 12.8 & 18.4 & 48 & 64 \\
\hline
\end{tabular}

These amounts are calculated according to the yield of the purified humic acids obtained per one kg of NWHC.

Table (3): Chemical and spectroscopic characteristics of humic acids extracted from the humified Nile water hyacinth after $2 \mathrm{~h}$ soaking in $0.1 \mathrm{M} \mathrm{NaOH}$

\begin{tabular}{||c|c|l|c|}
\hline Parameter & Value & \multicolumn{1}{|c|}{ Parameter } & Value \\
\hline $\mathrm{C}(\%)$ & 57.04 & Empirical formula & $\mathrm{C}_{10} \mathrm{H}_{12} \mathrm{O}_{4} \mathrm{~N}$ \\
$\mathrm{H}(\%)$ & 5.67 & Absorpitivity in L of dissolved carobn ${ }^{-1} \mathrm{~cm}^{-1}$ & 9.4 \\
$\mathrm{~N}(\%)$ & 6.97 & $\mathrm{Q}_{4 / 6}$ & 4.74 \\
$\mathrm{O}(\%)$ & 30.32 & Average molecular weight (Da) & $15000-30000$ \\
$\mathrm{H} / \mathrm{C}$ & 1.123 & Total acidity (meq/g) & 7.39 \\
$\mathrm{O} / \mathrm{C}$ & 0.399 & COOHin (meq/g) & 2.64 \\
$\mathrm{~N} / \mathrm{C}$ & $\mathbf{0 . 1 0 5}$ & OH in (meq/g) & 4.75 \\
\hline \hline
\end{tabular}


The stability of the neural humate SS:

The humic substances are all relatively stable in soil and their stabilities depend up on the environment. The half life time of the lfuvic acid in the soil is between 10 to50 years, while the half life of humic acid is generally measured in centuries. (Weber, 2005).

According to the reported methodology and theoretical approaches (Chen et al., 1977, Abbt Brum and Frimmel, 1999), the spectral absorbances at the wavelengths $254,436,465$, $665 \mathrm{~nm}$ are used for characterization of humic acids. The absorbance at 254 and 436 is related to the functional group content of humic acids while that at 465 and $665 \mathrm{~nm}$ is related to the humic acid average molecular weight. Also, it was found that there was a statistical correlation between the absorbance at $465 \mathrm{~nm}$ and HAs free radical contents which in turn is related to their structures. Free radicals also play an important role in formation of metal humates complexes and in the physiological activity that humic acids are known to exert. (Riffadi and Schnitzer, 1972). Table (4) shows the absorbance measure-ments at the above wave lengths after different time intervals for natural. Humate SS. According to the above mentioined discussion the absorbance at $465 \mathrm{~nm}$ was chosen to kinetically follow the alternation of the natural. humates SS solution with time. According to, Oslon (1963):

$$
X / X_{o}=e^{-k t}
$$

Where $X=$ the concentration remaining at time $t$ which can be represented by the absorbance at time 24, 48, and 72 hour. $X o=$ the original concentration that can be represented by the absorbance at the initial time. The alternation rate constant $(k)$, the half life time, $\left(t_{0.5}\right)$ and the turn over time $\left(t_{0.95}\right.$ are calculated and their values were $6.281 \times 10^{-3}$ day $^{-1}$, 4.59 day and 19.9 day respectively.

It can be concluded that the natural humate SS changes with time. Fig. (1) Shows the UVvisible spectra of natural humates $S S$ at the different studied time intervals. All spectra obtained exhibit a monotonous decrease in the absorption with increasing the wave length as it occurs with humic acids. This general stability of the spectra reveals the stability of humic acid basic structure. The appearance of turbidity in the bright yellowish brown humate solution with time, may explain the slight difference observed upon the spectra which may result from the precipitation of some metal humates. Accordingly, it is preferable to use freshly prepared humates as possible to avoid these slight chemical changes which may reduce the activity of humates solution.

Table (4): The Spectral absorbance of the Nat. humates SS (0.045g HAs/L) at some particular wavelengths and different time intervals $\left(\right.$ Room temperature $\left.=25^{\circ} \mathrm{C}\right)$

\begin{tabular}{|c|c|c|c|c|c|c|}
\hline$\gamma^{\lambda \mathrm{nm}}$ & \multicolumn{6}{|c|}{ Absorbance } \\
\hline Time h & 254 & 400 & 436 & 465 & 600 & 665 \\
\hline 00 & 2.609 & 0.614 & 0.453 & 0.370 & 0.200 & 0.157 \\
\hline 24 & 2.590 & 0.591 & 0.425 & 0.346 & 0.171 & 0.129 \\
\hline 48 & 2.491 & 0.540 & 0.383 & 0.304 & 0.137 & 0.097 \\
\hline 72 & 2.446 & 0.476 & 0.325 & 0.255 & 0.099 & 0.063 \\
\hline
\end{tabular}

$t_{0.5}=4.59$ day, $k$ (decreasing rate constant $=6.281 \times 10^{-3}$ and $t_{0.95}=19.9$ day). 


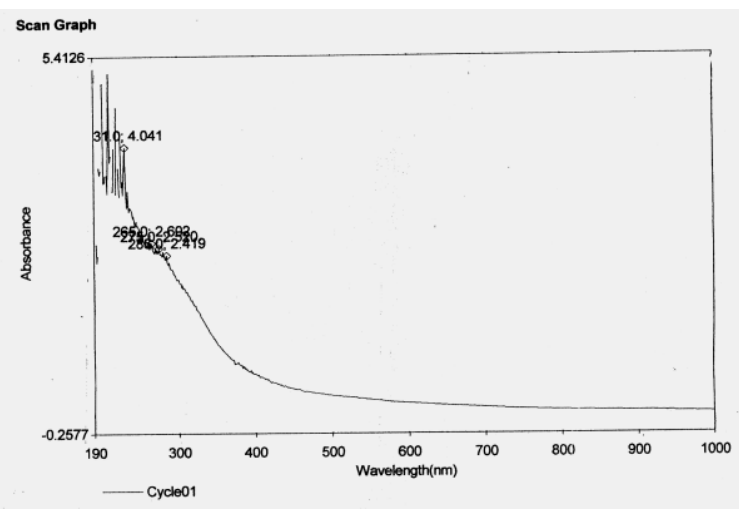

(a)

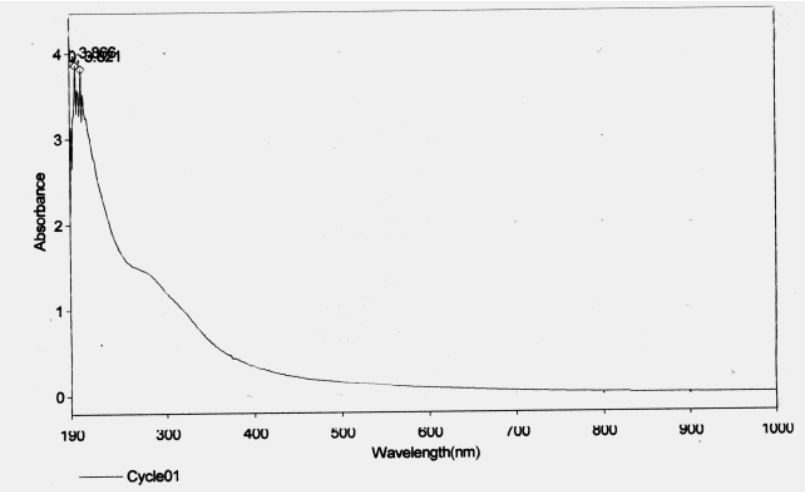

(c)

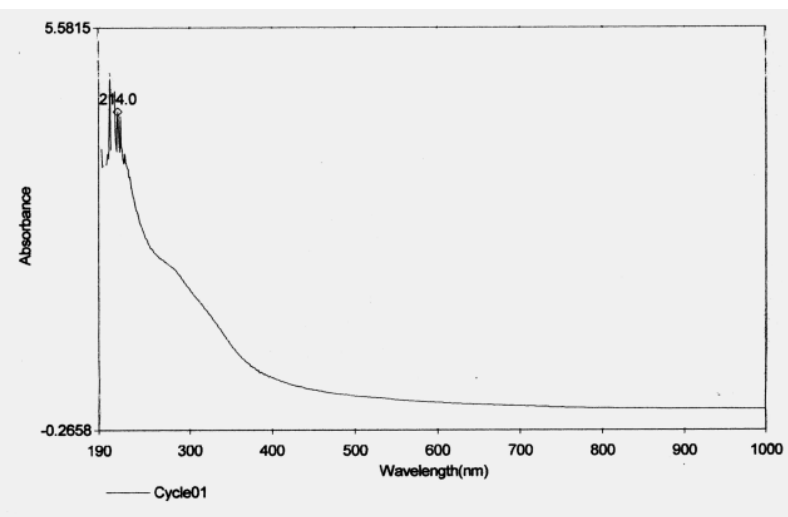

(b)

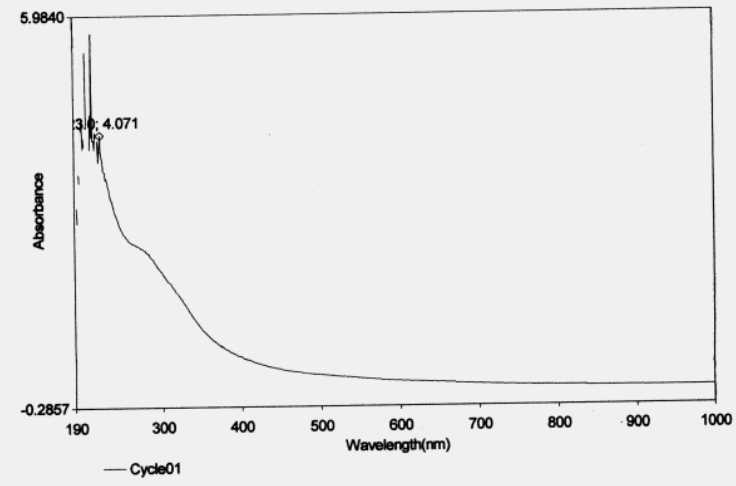

(d)

Fig. (1): UV-Visible Spectra of Nat humates- SS after different Time Intervals (a) $6 \mathrm{~h}$, (b) $24 \mathrm{~h}$, (c) 48h, and (d) $72 \mathrm{~h}$.

\section{Some analytical aspect of the natural humate SS:}

The humates are the metal salts of humic acids. The formation of humates is based on the abilities of both $\mathrm{COOH}$ and $\mathrm{OH}$ groups on the polymer to dissociate and the anions to bind to metal cations such as $\mathrm{Fe}, \mathrm{Cu}, \mathrm{Zn}, \mathrm{Mg}, \mathrm{Mn}, . .$. . etc. to form humates. (Tan, 1998). So, humic acids play an important role in the accumulation of heavy metals, and chelating the excess of metal cations out of the solution and storing them in chelate form for, latter use by plants in amounts suitable for plant growth. Some metals such as $\mathrm{Cu}, \mathrm{Zn}$ and $\mathrm{Pb}$ can be inactivated and converted to unavailable form to plants. Moreover, humic acids can serve as a carrier for toxic metals by forming stable complexes, (Baydina, 1996). Therefore toxic metals, anthropogenic chemicals and other pollutants are removed from solution by humic substances (Eladia et al., 2005). According to these facts heavy metals pollutants that may be found in Nile water (Abdel-Satar and Elewa, 2001) are expected to be inactivated by humic acids found in the naturale humate SS. In anther point of view, and according to Table (5) which shows some properties of natural humate SS and their contents from some important metals, the natural humates SS can be considered as a micro fertilizer. It can provide the plants with all essential elements. 
Table (5): Some analytical aspects of the natural humates SS

\begin{tabular}{|c|c|c|c|c|c|c|c|c|}
\hline Item & pH & $\begin{array}{c}\mathrm{TN} \\
(\mathrm{mg} / \mathrm{L})\end{array}$ & $\begin{array}{c}\text { TOC } \\
(\mathrm{mg} / \mathrm{L})\end{array}$ & $\begin{array}{c}\text { TDS } \\
(\mathrm{mg} / \mathrm{L})\end{array}$ & $\begin{array}{c}\mathrm{COD} \\
(\mathrm{mg}) \mathrm{O}_{2} / \mathrm{L}\end{array}$ & $\begin{array}{c}\text { DO } \\
(\mathrm{mg} / \mathrm{L})\end{array}$ & $\begin{array}{c}\mathbf{C d} \\
(\mathbf{p p m})\end{array}$ & $\begin{array}{c}\mathbf{P b} \\
(\mathbf{p p m})\end{array}$ \\
\hline Value & 6.7 & 12.76 & 120 & 2468 & 3000 & 4.69 & $<0.003$ & $<0.010$ \\
\hline \multirow{2}{*}{$\begin{array}{l}\text { Metal } \\
\text { (ppm) }\end{array}$} & $\mathbf{N a}$ & $\mathrm{Ca}$ & $\mathbf{K}$ & Mg & $\mathrm{Zn}$ & $\mathbf{F e}$ & Mn & $\mathrm{Cu}$ \\
\hline & 6400 & - & 5400 & 20 & 1.95 & 1.74 & 0.157 & 0.55 \\
\hline \multirow{2}{*}{$\begin{array}{l}\text { Metal } \\
\text { (ppm) }\end{array}$} & Al & B & $\mathrm{Cr}$ & Mb & $\mathbf{V}$ & Se & As & Co \\
\hline & 1.341 & 0.0498 & 0.004 & $<0.02$ & 0.0747 & nd & nd & $<0.003$ \\
\hline
\end{tabular}

nd =not detected

\section{Application of natural humate SS for maize plants:}

As seen in Table (6) there is an increase in the grain yield when the maize seeds were soaked in the natural humate SS for 24 hour before planting. The mean increase value of the crop after planting for two years, compared to the control was $3.715 \mathrm{ard} / \mathrm{fed}$. The L.S.D values in 2005 and 2006 were 2.06 and 2.32 respectively, this mean that the increase was significant and the crop responsed to the addition of the natural humates SS. In the same time the C.V values was 4.46 and 4.47 in both two years respectively, which means that the experiment in the field was homogeneous and showed no anomalous differences. In a next combined work, the effect of this treatment on the maize plants will include with complete descriptions of the effect of different treatments on maize growth and grain yield. It should be mentioned that the results have been obtained in a combined with the researchers in Corn Department, Field crops institute, ARC, Cairo, Egypt).

Table (6): Response of maize plants to natural humate SS (NHSS) after soaking seeds with it for 24 hours before planting at Ismailia research station in 2005 and 2006.

\begin{tabular}{|l|c|c||}
\hline \hline \multicolumn{1}{|c|}{ Year } & 2005 & 2006 \\
\hline Parameter & Grain yield (ard/fed) & Grain yield (ard/fed) \\
NHSS & 31.13 & 34.12 \\
Control & 26.88 & 30.91 \\
LSD $_{\text {oos }}$ & 2.06 & 2.32 \\
\hline
\end{tabular}

\section{REFERENCES :}

Abbt-Braun, G., F. H Frimmel., (1999): Basic characteristics of Norweqain NOM samples-Similarities and differences, Environ. Int. 2 5(2/3), 161-180.

Abdel-Satar, M.A. and A.A. Elewa, (2001): Water quality and environmental assessment of the river Nile at rosseta branch, the second International Conference and Exhibition for life and Environment. 3-4:136-164.
Alken, G.R; p.MacCarthy; L. R. Maclom and S.R. Swift (1985): Humic substances in soil, sediment, and water, John Willey and sons, New York

APHA, AWWA, and WPCF (1995): Standard method of the examination of water and waste water, $16^{\text {th }}$ ed New York.

Arancon N. Q., C.A. Edwards, P. Birman, C. Welche, and J.D. Metzger, (2004): Influences of vermicomposts on fild srtraw berries: 1-Effect on growth and yield Bioresource Techn. 93; 145-153. 
Ayuso, M., T. Hernandez and C. Garcia (1996): Effect of humic acid fractions from urban wastes and other more elevated organic material on seed germination J. Sci. food Agric 72, 461-468.

Badr, H.M (2003): Studying the chemical characteristics of humic acids extracted from soil and stable mannure fuel as a new sources and testing its effect on seed germination. Bulletin of Faculty of Science Al-Azhar University, 14, No2, 129-144.

Baydina, N. L, (1996): Inactivation of heavy metals by humus and zeolites in industrially contaminated soils. Eurasian Soil Science, 28(1), 96-105.

Chen, Y., N. Senesi., and M. schnitzer, (1977): Information provided on humic substances by $E_{4} / E_{6}$ ratio. Soil sci. Soc. Am. J. 41, 352-358.

Eladia M. P. Mendez, J. Havel and J. patocka (2005): humic substances- compounds of still unknown structure: application in agriculture, industry, environment and biomedicin J. Appl. Biormendiain., 3 ISSN 1214-0287.

Garcia D., J. Cegarra, A. Roig, and M. Abad. (1994): Effect of different extraction temperature on the characteristics of humic acids fertilizers obtained from lignit, Biores Technol. 47:103-106.

Ludmila T.S., E.A. Gabbbour, G. Davies (2005): Geoderma, 07,007 available online at www, science direct.com.

Olson J.S. (1963): Energy storage and the balance of producers and decomposers in ecological system. Ecdogy 44: 322-331.

Rice, J.A. and P. MacCarthy. 1991. Statistical evaluation of the elemental composition of humic substances. Org. Geochem. 17: 635- 640 .
Riffadi, R., and M. Schnitzer (1972): Electron spin resonance of humic substances. Soil Sci. Soc. Amer. proc, 36, 301-305.

Schnitzer M. and U.C Gupta, (1965): Determination of acidity in soil organic matter, Soil Sc. soc. Amer. Proc 29, 274-277.

Sharma, P.K and K.P. Goel, (1987): Decomposition of water hyacinth (Eichhornia Crassipes) (MART) sloms. Int. J. Ecol. Environ. Sci B.; p 13-17.

Sidique, M. and M. M. Alam. (1990): Treatment of water hayacinth tissue to obtain useful products, Biological Wastes 33, 263-274.

Stevenson, F.J. (1982): Humus chemistry: Genesis, composition, reactions. 2nd ed. Willey Interscience, New York.

Tan, K. G. (1998) Principles of soil chemistry, Mancel Dekker. New York

UnsaL, T and S. Sonay. Some chemical characteristics of humic acids extrctewd from different organic wastes [on line] 10/12/2006 <http://, Soil Science Department, Agricultural Faculty Ankara University 06110 Ankraa Turkey, Firefox Docoment.

Weber, J. Definition of soil organic matter [on line], 14/3/2007 <http://, Dept. of soil science, agriculture and environment protection of the Agriculture University of Wroclaw, Poland. Firefox Document.

Wild, S.A. (1979): Soil and plant analyses of trees (s) and culture, UK.

Yamada, E., T. Ozaki and M. Kimura (1998): Determination and behavior of humic substances as precursors of trihalomethane in environmental water, Analytical Sciences April 1998, 14, 327-332

Zerrudo V. J., B.O. Tadena and M. A. Exconde (1983): Water hyacinth for paper manufacture. NSTA, Technology Journal Oct. - Dec. 83, 43-48. 


\section{صناعة ورد النيل}

الجزء الأول: الخواص الكيميائية لأحماض الهيوميك المستخلصة من نبات التئ وردد النيل المتحلل

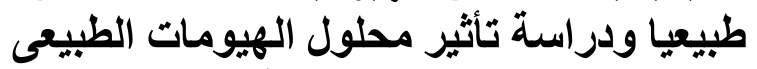

على محصول الأرة الثامية من الحبول الثبوب الطبيف

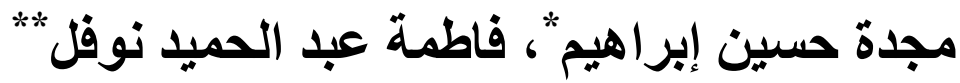

*قم الكيمياء - كلية العلوم فرع جامعة الأزهر للبنات - مدينة نصر إهر

|"معه المحاصيل الحقلية هيئة البحوث الزراعية - القاهرة

مادة الهيومس هى إحدي النواتج الطبيعية لتحلل المواد النباتية وإحيوانية، وتثمل ثلاثة مكونات هى أحماض الهيوميك (تذوب

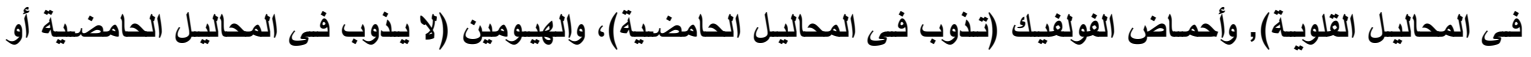

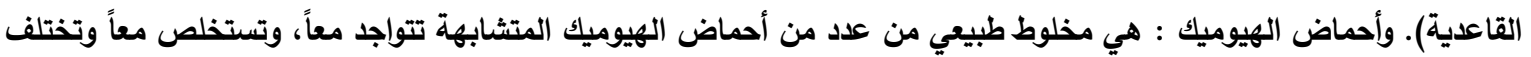

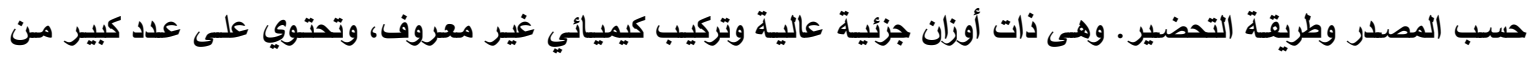

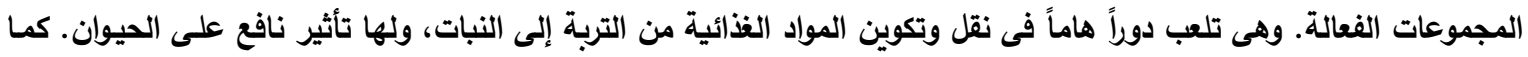

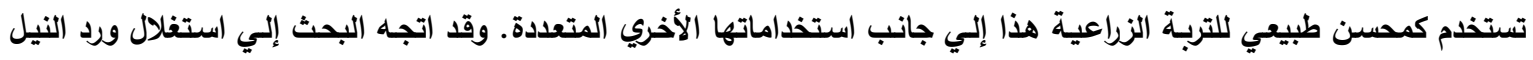

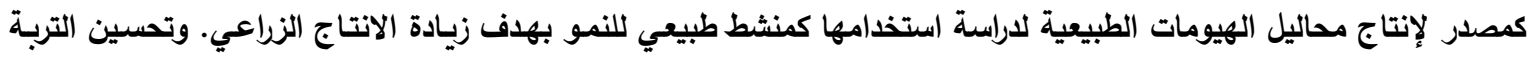

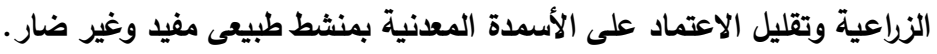

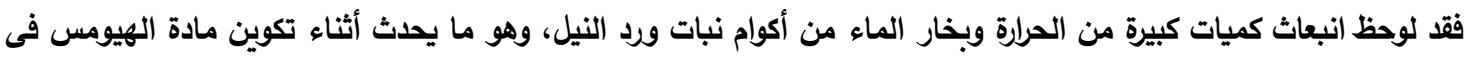
بعض المصادر النباتية, لذلك فقد تم نقع النبات بعد تحلله وتجفيفه والتخلص من الأجزاء التي لم تتحلل كلما أمكن فى محلول

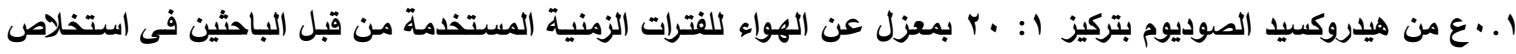

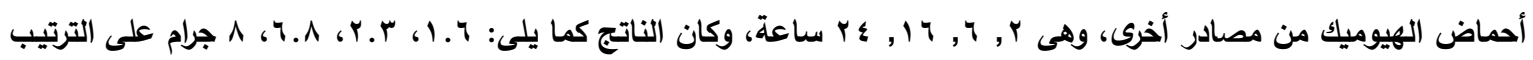

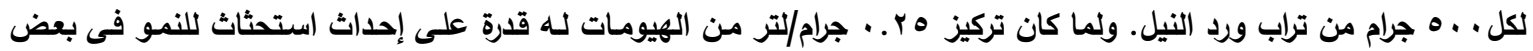

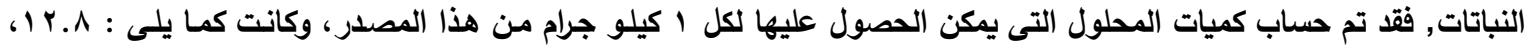

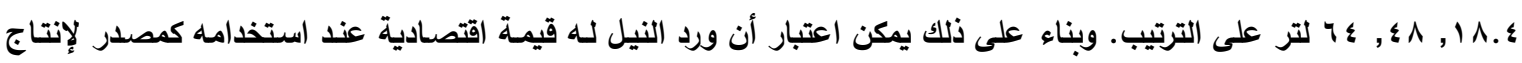

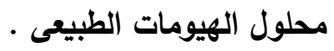
وأوضح التحليل العنصري للأحماض المستخلصة بعد ب ساعة والمنقاة أن نسب الـ C:H:N:O متطابقة مع النسب المعروفة لأحماض الهيوميك وأن الصيغة البنائية الأولية للأحماض هى ل (0.105), H/C(1.123), O/C(0.399) كذلك تم تعيين محتوى الأحماض من مجموعات الكربكسيل والكيدروكسيل.

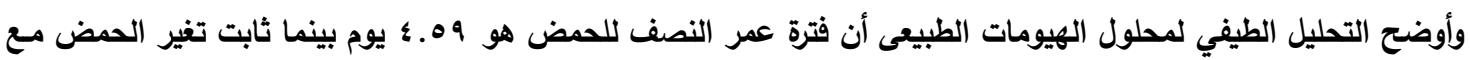

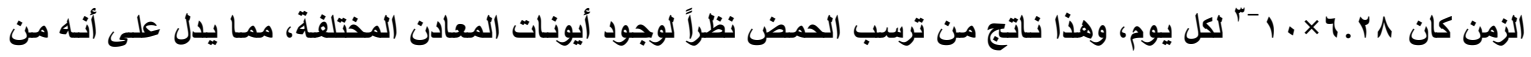

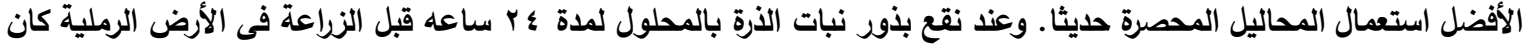

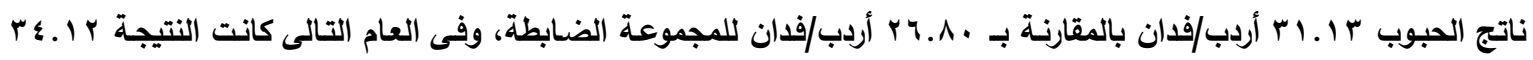

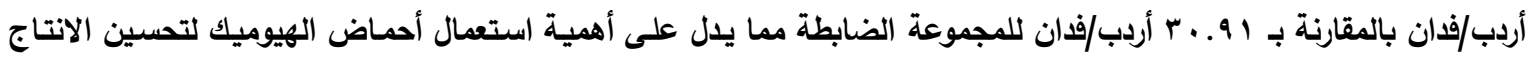
وتقوية نبات الذرة , وهذا يتفق مع ما تم نشره عن تأثير أحماض الهيوميك على النبات فى المراجع المختلفة. 